\title{
THE SHADOW SIDE OF SECOND-PERSON ENGAGEMENT: SIN IN PAUL'S LETTER TO THE ROMANS
}

\author{
SUSAN GROVE EASTMAN
}

Duke University

\begin{abstract}
This paper explores the characteristics of debilitating versus beneficial intersubjective engagements, by discussing the role of sin in the relational constitution of the self in Paul's letter to the Romans. Paul narrates 'sin' as both a destructive holding environment and an interpersonal agent in a lethal embrace with human beings. The system of self-in-relation-to-sin is transactional, competitive, unidirectional, and domineering, operating implicitly within an economy of lack. Conversely, Paul's account in Romans of the divine action that moves persons into a new identity of self-in-relationship demonstrates genuinely second-personal qualities: it is loving, non-transactional, noncompetitive, mutual, and constitutive of personal agency.
\end{abstract}

\section{THE QUESTION OF THE SHADOW SIDE}

At the end of the conference on 'The Second-Person Perspective in Science and the Humanities' hosted by the Ian Ramsey Centre for Science and Religion at Oxford in July 2013, a question was raised: 'What about the "shadow side" of second-person relationships?' The question highlights urgent issues that in turn press for further discussion. In the intensely intersubjective engagement that occurs between parent and child, what happens when the parent is so inwardly divided, overrun by aggression, or simply depressed and withdrawn, that the child suffers significant psychological if not also physical trauma? ${ }^{1}$ What of relationships that

${ }^{1}$ See the questions posed by Vasudevi Reddy, 'A Gaze at Grips with Me', in Joint Attention: New Developments in Psychology, Philosophy of Mind, and Social Neuroscience, ed. Axel Seemann (Cambridge, MA: MIT Press, 2011), pp. 137-157 (p. 150), and discussion of infant interaction with depressed and borderline personality mothers, in Peter Hobson, The Cradle of Thought (London: MacMillan, 2002), pp. 123-181. 
are abusive? Are such interactions to be considered second-personal? Perhaps not; perhaps there is a line beyond which an interaction is more of an 'I-It' than an 'I-Thou' relation, in that one participant is depersonalized and objectified by the other. But where is that line, and are there states that are even worse than depersonalization, states in which one participant understands enough about typical intersubjective engagement to be able to recognize but pervert the capacity for secondpersonal engagement of the other, as in acts of intentional cruelty? ${ }^{2}$

To put the issues slightly differently, studies of human development and the development of mind through very early interaction between infants and adults have deepened and intensified our knowledge of the degree to which infants are vulnerable to the relational systems in which they are embedded from birth (and before). This is not to say that infants are born as completely passive blank slates. Clearly this is not the case. Rather, infants reach out for relationship and mimetically interact with their caregivers almost immediately after birth, as studies of neo-natal imitation have demonstrated. ${ }^{3}$ That immediate interpersonal engagement awakens the interest and awareness of the infant, including an awareness of the self as the object of the parent's attention to the infant; as Vasudevi Reddy has argued, '[I]t is the other's attention at grips with the infant that makes attention exist for the infant.' ${ }^{4}$ Even more strongly, Reddy claims, ' $[Y]$ ou have to be addressed as a subject to become one. ${ }^{5}$ In other words, from the very beginning the person is irreducibly a 'person-inrelationship-to-another.' If this is the case, then the actions, attitude and gaze of the 'other' have profound power in the constitution of the self, for good or for ill. When parents basically love and attend appropriately to their infants, the infants flourish. But when for a myriad of reasons parents do not, or cannot, attend appropriately to their children, when

${ }^{2}$ Here I use the term 'intersubjective engagement' to refer to primary (dyadic) intersubjective engagement between infant and caregiver, rather than to developmentally later secondary (triadic) intersubjective attention to a third object. See Johannes Roessler, 'Joint Attention and the Problem of Other Minds', in Joint Attention: Communication and Other Minds. ed. Naomi Eilan et al. (Oxford: Clarendon Press, 2005), pp. 230-233.

${ }^{3}$ For early studies of infant imitation, see Andrew Meltzoff and M.K. Moore, 'Imitation of facial and manual gestures by human neonates', Science 198 (1977), 75-78.

${ }^{4}$ Reddy, 'A Gaze at Grips with Me', p. 138.

${ }^{5}$ Reddy, How Infants Know Minds (Cambridge, MA: Harvard University Press, 2008), p. 32 .

${ }^{6}$ This formulation of intersubjective identity comes from Hobson, The Cradle of Thought, p. 183. 
their intersubjective engagement with the child is disturbed, insufficient or destructive, the agency and cognition of the child must also be affected. ${ }^{7}$ For example, what happens when the parental 'gaze' towards the infant is a blank stare that ignores the child's increasingly frantic bids for attention? And how will that child in turn interact with others?

These questions point to the 'shadow side' of second-person relatedness: the relational systems in which human beings are embedded and participate have enormous power for ill as well as for good. In this paper I will explore the characteristics of harmful versus beneficial intersubjective engagements, by discussing the relational constitution of the self in a particular New Testament text - Paul's letter to the Romans. Specifically, I will discuss the ways Paul narrates 'sin' as both a destructive holding environment and an interpersonal agent in a death-dealing embrace with human beings. For Paul, sin is not solely or even primarily an attribute or action of individual human agents, but rather operates in a dyadic relationship with humanity, in which persons' desires and actions are co-opted for sin's purposes. The characteristics of this relational system emerge in Paul's narrative accounts of sin and open the door to further consideration of factors affecting the intersubjective formation of persons.

\section{SECOND-PERSON RELATEDNESS}

Peter and Jessica Hobson discuss critical factors requisite in the development of genuinely second-personal engagement and joint attention. They take as 'pivotal ... the propensity to identify with the attitudes of other people. ${ }^{8}$ Elsewhere they describe this identification as more than imitation; it is a kind of emotional and psychological sharing that

involves movement toward and adoption of aspects of another person's psychological stance vis-à-vis objects or events, and assimilation of this [stance] within one's own now-expanded subjective state. There is a sense in which one 'participates in' the other person's state, yet maintains

7 For compelling evidence supporting this claim, see the studies of children in Romanian orphanages, which indicate a significant decrease in brain development in institutionalized children deprived of normal human interaction. Scientific American, 308 (April 2013), 62-67. Published online: 19 March 2013 | < doi:10.1038/ scientificamerican0413-62> [Accessed 9 October, 2013.]

${ }^{8}$ Peter Hobson and Jessica Hobson, 'Joint Attention or Joint Engagement? Insights from Autism', in Seemann, Joint Attention, pp. 115-136 (p. 117). 
awareness of 'otherness' in the person with whom one is sharing, while also being affectively involved from one's own standpoint. ${ }^{9}$

This process of assimilation to the other's affective and psychological state without absorbing the other into oneself includes shared looks and emotions and a united psychological stance. This is second-personal interaction because it clearly involves an 'I' and a 'you' in mutual awareness. In primary intersubjectivity, parent and child share awareness of shared attention to the infant, such that the infant experiences herself as the object of the parent's gaze. In triadic joint attention, the focus widens to include a common stance towards third objects or events, so that two persons share an awareness of a shared focus. ${ }^{10}$ Both cases require mimetic assimilation paired with respect for the otherness of one's relational partner; these notions of assimilation and otherness will guide my discussion of genuine versus pseudo second-person relatedness.

\section{SIN AND THE SELF IN ROMANS}

Before tracing the relationship between $\sin$ and human beings in Romans, two brief observations are in order. ${ }^{11}$ First, simply by virtue of

9 Ibid., pp. 120-121. They develop this point in depth, citing Freud's claim that 'identification is not simply imitation but assimilation', and the comments of MerleauPonty: 'Mimesis is the ensnaring of me by the other, the invasion of me by the other; it is that attitude whereby I assume the gestures, the conducts, the favorite words, the ways of doing things of those whom I confront. ... I live in the facial expressions of the other, as I feel him living in mine.' See Sigmund Freud, 'The Interpretation of Dreams', in J. Strachey, ed. The Standard Edition of the Complete Psychological Works of Sigmund Freud, vols 4-5 (London: Hogarth, 1900/1953), p. 150; M. Merleau-Ponty, 'The Child's Relations With Others', in The Primacy of Perception (Evanston, IL: Northwestern University Press, 1964), pp. 118, 145-146. Quoted in Hobson, 'Joint Attention or Joint Engagement', p. 130.

${ }^{10}$ Vasudevi Reddy, 'Before the "Third Element”: Understanding Attention to Self', in Joint Attention: Communication and Other Minds: Issues in Philosophy and Psychology, ed. Naomi Eilan et.al. (Oxford: Clarendon Press, 2005), pp. 85-109; Peter Hobson, 'What Puts Jointness into Joint Attention?', Eilan et al., Joint Attention, pp. 185-204 (p. 185). See also the discussion of joint attention in Andrew Pinsent, The Second-Person Perspective in Aquinas's Ethics: Virtues and Gifts (New York; London: Routledge, 2012), pp. 47-49.

${ }^{11}$ The interpretation of Romans is highly contested territory. For general support of the interpretation I propose here, see Leander Keck, Romans (Abingdon New Testament Commentaries: Nashville: Abingdon, 2005); Paul Meyer, 'Romans: A Commentary', in The Word in This World: Essays in New Testament Exegesis and Theology (NTL; Louisville: Westminster John Knox, 2004); Robert Jewett, Romans: A Commentary (Hermeneia; Minneapolis: Fortress, 2007). 
its genre Romans is a second-personal communication, written from a second-person standpoint. It is, after all, a letter written by a particular 'I' - Paul - to a plural 'you' - the members of the churches in Rome, with whom Paul desires a reciprocal relationship of mutual encouragement (1:12) and from whom he hopes for assistance $(15: 24,30)$. Although he did not found these churches, he ends his letter with lengthy greetings to individuals by name (16:1-16). Thus the beginning and ending of this letter bracket everything else Paul says within an affective, interactive bond of love: Romans is not a unidirectional sermon, but a relational appeal. Second, Paul's account of sin and human beings takes on a spiral structure in Romans 1-8, in which three repetitive, overlapping narratives progressively expand the cast of characters and then intensify the personal and emotional effects of Paul's language. ${ }^{12}$ The first account depicts sin as what human beings do (1:18-5:12); the second narrative depicts sin as an agent that acts in human history (5:12-7:7); the third narrative dramatizes the relationship between this agent and the self (7:7-25). In their storied qualities, these narratives enclosed within this second-personal letter are themselves second-personal engagements with Paul's readers that draw them increasingly into the drama of sin's lethal involvement and God's life-giving engagement with human beings. ${ }^{13}$

\section{SIN IS WHAT HUMANS DO}

The first occurrence of 'sin' in Romans is as a verb that describes what all human beings do: 'All who have sinned without the law will also perish without the law, and all who have sinned under the law will be judged by the law' (2:12). Shortly thereafter Paul claims, 'all have sinned and fall short of the glory of God' (3:23). This depiction of sin as a human action is what one expects to hear from Paul. There are, however, only

${ }^{12}$ See Leander E. Keck, ' [W] hat makes Romans 1-8 tick is the inner logic of having to show how the gospel deals with the human condition on three ever-deeper levels, each understood as a dimension of the Adamic condition: the self's skewed relationship to God in which the norm (law) is the accuser, the self in sin's domain where death rules before Moses arrived only to exacerbate the situation by specifying transgression, the self victimized by sin as a resident power stronger than the law.' 'What Makes Romans Tick?' in Pauline Theology: Volume III: Romans, ed. David M. Hay and E. E. Johnson (Minneapolis: Fortress, 1995), pp. 3-29 (p. 26).

${ }^{13}$ For discussion of stories as 'second-person accounts' see Eleonore Stump, Wandering in Darkness: Narrative and the Problem of Suffering (Oxford: Oxford University Press, 2010), pp. 77-81. 
four verses in the letter where sin is a verb with human beings as the subjects: Romans 2:12, 3:23, 6:15, and 5:12, which will be discussed later. ${ }^{14}$ In these verses, sin sums up other ways of describing human actions characterized as evil. Paul uses somewhat interchangeable verbs to depict this state of affairs: humans 'accomplish' evil (katergazomai; 2:9); they 'do' evil (poieō; 3:8); they 'practice' it (prassō; 1:32; 2:1-3). This human activity results from and further enacts a systemic condition into which human beings have been 'handed over' (paradidomi) by God as a result of their primal idolatry. This condition includes a kind of cognitive impairment: they are delivered over to an 'unreasoning mind' (adokimon noun) that corresponds to their failure to acknowledge God (edokimasan; 1:28).

Thus sinful human actions are further characterized by a link between distorted cognition, false speech, and evil acts, all of which occur within and among persons: 'there is no one who shows kindness, there is not even one ... Their throats are opened graves; they use their tongues to deceive ... Their mouths are full of cursing and bitterness ... Their feet are swift to shed blood.' (3:9-18) We note in particular here the loss of understanding, the proliferation of false and destructive speech, and the violent breakdown of human relationships.

In this first part of Paul's account of sin, then, the verb denotes the human perpetration of horrifying lies and violence. Paul does not hesitate to label human beings as 'sinful' or 'sinners' (3:7; 5:8, 19; using the substantive harmartōlos). Yet at the same time, human 'sinners' act as those who have been handed over into a state of distorted cognition, and who therefore are 'under the power of sin' (3:9). That is, their actions do not enact the unqualified decisions of unfettered minds; they do not see clearly, and in this sense they do not act as free agents. Rather, in sin's first appearance as a noun denoting a power 'over' all people, we hear a hint of its role in the drama of human suffering and dereliction. Furthermore, Paul's analysis is global: 'all, both Jews and Greeks, are under the power of sin.' This universal condition means there is no room here for labelling some as sinners and some as righteous. Indeed, a good part of Paul's argument leading up to this statement is a series

14 The verb hamartanō appears in the indicative aorist active twice in $2: 12$, once in 3:23 and 5:12, and in the subjunctive in 6:15: 'Should we sin because we are not under law but under grace? By no means!' In contrast, the noun hamartia appears forty-eight times in Romans. 
of second-personal warnings addressed directly to his readers, warning them against judging others as sinners in distinction from themselves $(2: 1-6,17-29) .^{15}$

The depiction of $\sin$ as something that humans do is thus already qualified by the impairment of human agency under an external and oppressive power. It is this oppressive power that comes to the fore in Paul's second narrative, which contains the thickest cluster of harmartia language in the letter. In Romans 5:12-8:3 he develops the personification of $\sin$ itself as a distinct entity that acts on and through human beings; here sin is the partner in an intersubjective constitution of persons-in-relationship.

\section{'SIN' IS WHAT SIN DOES IN AND THROUGH PERSONS-IN-RELATIONSHIP-TO-SIN}

In Romans 5:12, immediately after proclaiming salvation from wrath, reconciliation with God and the hope of salvation through the death of Christ, Paul abruptly reintroduces the topic of sin. Now, however, sin is emphatically the subject of active verbs: '[S]in came into the world through one man and death through sin, and so death spread to all human beings so that all sinned. ${ }^{16}$ It is through the disobedience of the 'one man', Adam, that 'the many were made sinners' (5:19) precisely because they existed in a cosmos in which death reigned $(5: 14,17)$ and sin reigned through death (5:21). For this reason the human condition is one in which all die and all sin, and Paul traces the cause of this catastrophe back to the primal ancestor whose trespass unleashed the lethal rule of sin and death in human history. For the limited purposes of this paper, what is notable here is the thoroughgoing presumption of relational identity that undergirds Paul's argument. Humanity is so intimately intertwined that one primal person's actions affect all and even constitute all as 'sinners'. For Paul, 'six degrees of separation' is too much - here there are zero degrees of separation between the first ancestor and all human beings.

15 See Jewett, Romans, pp. 192-237.

16 The translation of this verse is controversial; it also could be translated, 'death spread to all human beings because all sinned', thereby laying the blame for death at the feet of human beings. In my view the first translation has stronger support both grammatically and in the context of the larger argument. See Jewett, Romans, pp. 375376 , for discussion of the grammatical issues. 
Furthermore, sin is not an inert characteristic passed on from generation to generation; rather, it is a self-aggrandizing active agent bent on a hostile take-over of the human race. Sin 'increased' (5:20) and 'reigned in death' (ebasileusen; 5:21). Human beings can be 'in sin' (6:1) as well as 'under sin' (3:9), so that sin denotes a realm of existence like a household named after the slave master who rules over it (6:6-11). Sin 'lords it over' mortal bodies (6:12-13) and deals out death to its slaves (6:16-17, 20-21). In this context, the statement, 'The wages of sin is death' does not mean that God punishes sin with death, but that sin pays its minions with death; conversely, 'the free gift of God is eternal life in Christ Jesus our Lord' means that, in contrast with the tyrant sin, God freely gives life in the new relational identity constituted in Christ. Indeed, that new relational identity is a gift and is life, whilst sin's interaction with human beings is transactional and thereby death-dealing. Its slaves are 'free from righteousness' in that they are obeying sin rather than righteousness, but the payback for their actions is death (6:20). Within this transactional system even the law of God operates as a mode of control under sin's direction, as noted in the verse, 'The law came in to increase the trespass' (5:20). In other words, to be under the law rather than the gifted realm of God's grace is implicitly to be in the realm where sin rules (6:14); the law is not strong enough to break sin's grasp, but rather becomes a weapon in the hands of this oppressive regime.

Paul has personified sin as an agent in a death grip with human beings. Here is an account of human beings constituted as 'sinners' in a participatory relationship with sin as a distinct and hostile acting subject. Over against this relationship, he names a different, more powerful participatory engagement with Christ. Whereas sin binds its human minions in a transactional interaction, the constitution of personhood 'in Christ' is characterized by an abundance of 'grace'; this constitution occurs in a relationship qualified by gift rather than wages $(5: 17 ; 6: 23)$. Whereas sin's rule overtakes and diminishes the agency of its 'slaves', the dominion of grace strengthens the agency of those who receive grace, so that they themselves 'reign in life through the one man Jesus Christ' (5:17).

In Romans 5:12-21, Paul contrasts these two relational matrices through a third-person account of sin's dominion and the more powerful dominion of grace through Christ. In 6:1-7:6 he switches to the second-person plural to address his listeners and occasionally assumes the posture of an inclusive first-person plural 'we'. Just as the presumed 
notion of persons in regard to sin is relational and participatory, so the basis of his appeal to the Romans is their shared baptism 'into' Christ's death so that they might also live together with Christ and each other (6:2-9). Paul conceives of this sharing in Christ's death as a real event in which 'the body of sin' has been destroyed. Metaphorically, this 'body of sin' denotes persons' bodily participation in the relational matrix of sin and death; it has been overthrown by a more powerful relational identity, which also is embodied, being constituted 'in Christ', 'under grace', and through 'the body of Christ' $(6: 11,14 ; 7: 4)$. This is the agency of humanity-in-relationship-to-an-other that is both transcendent and immanent, and Paul repeatedly qualifies the relationship as one of gift (charisma) and overflowing, limitless grace (charis). ${ }^{17}$ Remarkably, the gift is more powerful than sin or sin's use of law. Thus Paul confidently encourages his hearers: 'sin will not rule over you, for you are not under law but under grace.' $(6: 14)^{18}$

\section{THE SELF'S CRY FOR FREEDOM}

Paul could stop here, but he does not. Yet a third time he narrates the drama of sin and redemption, but now he speaks in the first-person singular (7:7-25). Here the 'I' dramatically performs the experience of the self-in-relation-to-sin and to sin's cooptation of the law. The action of sin is portrayed in increasingly forceful terms, and the human actor recedes increasingly into the background. Sin uses the law of God as a military staging area (aphorme $)$ from which to launch its lethal attacks on humanity, specifically by using the law to awaken covetous desires $(7: 8)$ and to deceive and kill $(7: 11)$. In relationship to sin, the self seems weakened in its own capacity to act effectively. So whereas Paul has depicted the relational matrix of grace as one in which divine action

\footnotetext{
${ }^{17}$ Rowan Williams catches the sense of this non-competitive and transcendent 'Other' when he describes the 'soul' as 'a whole way of speaking, of presenting and "uttering" the self, that presupposes relation as the ground that gives the self room to exist, a relation developing in time, a relation with an agency which addresses or summons the self, but is in itself no part of the system of interacting and negotiating speakers in the world'. Lost Icons: Reflections on Cultural Bereavement (London; New York: Continuum, 2003), p. 196.

${ }^{18}$ For the notion of being 'under grace' and the powerful construction of a new human agent therein, see John M. G. Barclay, 'Under Grace: The Christ-Gift and the Construction of a Christian Habitus', in Apocalyptic Paul: Cosmos and Anthropos in Romans 5-8, ed. Beverly R. Gaventa (Waco: Baylor University Press, 2013), pp. 59-76.
} 
strengthens human agency rather than competing with it, he depicts sin's agency in competition with the wishes of the self:

I do not know (ginōskō) what I am bringing to pass (katergazomai). For I do not do (prassō) what I want, but I do (poiō) the very thing I hate. Now if I do (poiō) what I do not want, I agree that the law is good. But in fact it is no longer I who brings it to pass (katergazomai), but sin that dwells within me.

For I know that nothing good dwells within me, that is, in my flesh.

For I can want the good, but I cannot accomplish it.

For I do not do (poīo) the good I want, but the evil I do not want is what I do (prassō).

Now if I do (poī) what I do not want, it is no longer I who brings it to pass (katergazomai), but sin that dwells within me.

So I find it to be a law that when I want to do what is good, evil lies close at hand. (7:15-21)

We recall that in Paul's first account of sin, human beings are 'sinners' who 'sin'; here sin itself is the surpassing 'sinner' (7:13). Now a conflicted dyadic agency that Paul names 'I-yet-not-I but sin-dwelling-in-me' performs actions previously ascribed to human beings, using the same interchangeable active verbs: doing (poiō), practicing (prassō) and bringing to pass (katergazomai) evil. In this self-in-relation, the agency of sin overrides the wishes of the self, so that Paul repeats verbatim, 'It is not I bringing it to pass, but sin dwelling in me.' Here is an interaction in which one partner overtakes the agency of the other, who says, 'I thought I was acting, but really it was sin acting in me.'19

Paul says quite precisely, 'I want to do the good, but what sin accomplishes through me is evil.' Or to paraphrase further, 'I want to do the good, and even think I am doing the good, but find that the results of my actions are evil. So I must not be the one acting, but sin dwelling in me.' Most scholars do not think that Paul is speaking in explicitly autobiographical terms here, but perhaps aspects of his experience can illuminate his meaning. In his letter to the Philippians, for example, he describes himself paradoxically 'as to zeal a persecutor of the church, as

19 This discussion of agencies merits further development which is beyond the scope of this essay. See in particular the importance of 'congruence between anticipated outcome and actual outcome' for a personal sense of agency, in Elisabeth Pacherie, 'The Phenomenology of Joint Action: Self-Agency versus Joint Agency', Seemann, Joint Attention, pp. 343-390. 
to righteousness under the law blameless' (Philippians 3:6). Paul thought he was zealously keeping the law and serving God, but discovered that at the same time he was opposing God..$^{20}$ Something similar seems to be going on in Romans 7:15-20, where the problem is not one of intentions, but of actions that result in death. In fact the 'I' does not examine or judge his intentions. He does not say, 'Even when I do the good, my desires are selfish or sinful.' He does not say, 'I want to do the good, but am powerless to act.' Rather, an alien agent called sin intrudes between the actions of the one who desires the good and the effects of those actions, producing evil rather than the desired good. ${ }^{21}$ In this way Paul drives a wedge between the self that seeks the good and sin as an occupying power. Furthermore, nothing in the text says that Paul here is only talking about believers or unbelievers, regenerate versus unregenerate humanity, or any other re-inscription of a divide between 'godly' and 'ungodly' human beings. Rather, this 'I' who wants the good but finds even that desire for the good exploited by sin is all humanity 'in the shadow of Adam. ${ }^{22}$

So within Paul's account of the competing agencies of self and sin, sin confiscates the self's desire for the good for its own purposes. Nonetheless there is not a complete erasure of the self, which continues to 'know' (7:18), to 'want' $(7: 15,16,19,20)$, to 'find' ( $7: 21)$, to 'see another law at work in my members' (7:23), and even to 'delight in the law of God in my inmost self' (7:22). The self here is described as occupied territory, its subjectivity colonized by an oppressive foreign power, its members mobilized for actions contrary to its deepest wants, but yet it remains cognizant of its loss of freedom. It experiences this combination of cognizance and crippled capacity as inner division, which is the internalization of sin's lethal embrace.

\section{SECOND-PERSON REFLECTIONS}

In second-personal terms, we might say that the self internalizes the relational matrix that Paul calls sin, and experiences that internalization

${ }^{20}$ Jewett, Romans, pp. 468-470.

21 'Sin causes an objective kind of contradiction between willing and achieving the good.' Jewett, Romans, p. 467.

22 The phrase comes from Otfried Hofius, 'Der Mensch im Schatten Adams', in Paulusstudien II (WUNT 143; Tübingen: Mohr Siebeck, 2002), pp. 104-154. For my claim that all humanity is in view here, see also Paul W. Meyer, 'The Worm at the Core of the Apple: Exegetical Reflections on Romans 7', in The Word in This World, pp. 57-77. 
as a division within itself. Peter Hobson discusses the internalization of patterns of relationship by citing Freud's advice to really listen to severely depressed patients:

Freud concluded that, although one seems to be listening to a single, individual patient expressing his woes, in effect one is witnessing a relationship. An internal relationship. And an unpleasant relationship at that. There is one part of the patient who cruelly accuses and torments another part of the patient.... The patient is the perpetrator as well as the victim of the horrible onslaught. Freud went further than this: he also suggested how this relationship becomes installed in the personality. It has been internalized from outside..$^{23}$

Similarly Paul narrates sin as both external and internal: human beings are 'in sin' and 'under sin', and yet also indwelt by sin. For this reason the self-in-relation-to-sin does not fully know its own actions; it is inwardly divided, it does not understand what it is doing, yet retains some awareness of its predicament.

The effects of such an internalized relationship might be traced out in a multitude of directions. The division within the self contributes to conflicted interaction with others. I noted above the competitive aspect of Paul's portrayal of sin in relationship to human agency: when sin increases, the human capacity for effective action decreases. Such interaction hardly qualifies for the notion of genuine second-personal engagement as empathetic, assimilating to the stance of the other and simultaneously respecting the other's difference. Rather, given the internalization of a competitive intersubjective relational matrix, what happens when persons share attention toward a third object? That is, how does such a distorted primary intersubjectivity open out to secondary or triadic intersubjective engagements? These are immense questions that are beyond the scope of this paper, but Paul's depiction of sin does point towards some possible effects. One might anticipate, for example, interactions characterized by conflict rather than shared enjoyment of an object. In a non-competitive relationship, shared desire is a mode of shared mind; perhaps in competitive relationships, triadic attention leads to the development of mimetic rivalry. ${ }^{24}$

${ }^{23}$ Hobson, The Cradle of Thought, pp. 162-162.

${ }^{24}$ See in particular Scott Garrels, 'Imitation, Mirror Neurons, and Mimetic Desire: Convergence Between the Mimetic Theory of René Girard and Empirical Research on 
In a detailed and moving account of a 'play session' between a child and a mother with borderline personality disorder, Hobson describes the gradual disintegration in their interaction. It began with competition:

The interchange began with the infant leaning across to take a carriage that was just within reach. The mother held on to the carriage so that the child could not take it, took up a figure herself, and said, 'Put the man in the train', while performing this action herself. ${ }^{25}$

Things went from bad to worse; at one point the mother tugged at the carriage while the child pulled it away. Although allowing the child to have the toy, the mother immediately turned her attention to another carriage rather than to her child. The mother attempted unsuccessfully to catch her child's attention, and the infant attempted to get the mother's attention, also unsuccessfully. In Hobson's words, 'There was a sense of impending chaos', as the mother continued to play without acknowledging her child's wants, and the child turned away from the mother. Towards the end of the session, 'The infant had managed to put her figure in her carriage, and for a brief instant she looked up to her mother, but they did not smile to each other. The infant moved her carriage so that the figure fell over; her mother tried to reach it, and the baby pulled the carriage away. Mother withdrew as if at a loss. ${ }^{26}$ Hobson observes, 'This mother found it very difficult to attune to her infant's current feelings and actions. Again and again she strove to impose her own focus of attention, or to intrude her own action, as the means to get her infant to behave in the way she wanted. ${ }^{27}$ Is this second-person relatedness? Or is it a shadow of second-person relatedness, in which some aspects of the framework of interaction and engagement are present but the substance of genuine joint attention is lacking? One senses a hollow facsimile of engagement without any real union of attention or desire, analogous to the ways in which Paul depicts the interaction between sin and the self as one in which sin overrides the wants of the self and shuts down its agency,

I do not mean in any way to suggest that this troubled mother is a personification of 'sin' in any form, including intentional cruelty. To the

Imitation', in Contagion: Journal of Violence, Mimesis, and Culture, Issue 12-13 (20052006), 47-86.

${ }^{25}$ Hobson, The Cradle of Thought, p. 130.

${ }^{26}$ Hobson, The Cradle of Thought, p. 131. Hobson is discussing attachment theory, not competition per se, but the competitive, or in his words, 'intrusive' qualities of the mother's interaction with her child thread throughout the account.

27 Ibid. 
contrary, by distinguishing between sin and the self, Paul provides a way to name the interpersonal difficulties without demonizing the person. ${ }^{28}$ The patterns of interaction display analogies with Paul's depiction of sin as a kind of debilitating relational system in which both mother and child are caught. It is worth emphasizing that the dyad of mother and child, or any dyadic relationship, never exists in a vacuum. The mother herself has been formed through other internalized relationships, and also she and her child are embedded in larger, complex social realities. In this case, Hobson describes the disjointed thinking and unresolved past traumas of the mother with borderline personality disorder, and correlates this with her inability to engage with her child. One wonders also if her 'intrusive' or competitive actions disclose psychological impoverishment, without enough emotional capital to sustain the suspension of her own needs for attention in order to attend to those of her child. Without help from other sources, the child in turn will suffer difficulties in thinking, integrating experiences, relating to others, and managing the stresses of life.

To return to Paul's depiction of sin, here sin is a relational matrix characterized by an economy of lack and competitive interactions. But Paul's depiction of sin is complex because he also narrates sin as an agent operating in and through human beings. Internalized, sin enters into a competitive interaction with the self: sin's power increases, and the self's agency decreases. The self experiences this internalized competitive relationship as inner division, a fragmentation of the self. ${ }^{29}$ Indeed, there are hints that the fragmentation can become so great that the self loses all differentiation between 'the sin that dwells in me' and its own desires. The person's own wants become opaque to her conscious awareness; she becomes subject to drives that she does not understand, and any help for her will include learning to distinguish between those drives and her own personhood. For example, narrative therapy with victims of anorexia teaches them to distinguish between their own voice and that of anorexia. ${ }^{30}$ When a young woman in recovery from anorexia

${ }^{28}$ On this dynamic see Andrew Delbanco, The Death of Satan: How Americans Have Lost the Sense of Evil (New York: Farrar, Straus \& Giroux, 1995).

${ }^{29}$ See Stump, Wandering in Darkness, pp. 125-127.

${ }^{30}$ Richard Maisel, David Epston, and Ali Borden, Biting the Hand that Starves You: Inspiring Resistance to Anorexia/Bulimia (New York: W. W. Norton \& Company, 2004). For a comparison of Paul's account of sin and therapy with victims of anorexia, see my 'Double Participation and the Responsible Self in Romans 5-8', in Gaventa, Apocalyptic Paul, pp. 93-110. 
says, 'I was at one with anorexia. ... The voice you heard was not mine', her self-description is hauntingly similar to the words of the self in Romans 7:17, 20: 'It is no longer I doing it, but sin which dwells in me.'31 We might say that Paul and this young woman are both utilizing what narrative therapists call 'a manner of speaking', a way of narrating the self as distinct from death-dealing powers and in need of liberation from them. ${ }^{32}$

Narrating sin as both a destructive relational environment and a hostile agent has many potential effects that invite further exploration. For example, Paul's transactional account of sin in comparison with the giftedness of gracious relationships as genuinely second-personal supports an understanding of his theology of redemption in nontransactional, second-personal terms. Similarly, the global scope of both sin and redemption undergirds his refusal to locate the origin of sin in any particular human beings or group, and thereby argues against an account of evil based on innate or developmental differences between persons. ${ }^{33}$ Again, Paul's participatory anthropology could be developed in conversation with notions of the interpersonal foundations of human cognition, empathy and agency. In the remainder of this paper, I will limit myself to the contrast between sin as a pseudo second-personal engagement and the self-in-relation-to-Christ.

\section{CHRIST AND THE SELF}

The contrast is most striking when the pattern of Romans 7:17, 20 is placed alongside Galatians 2:20. We recall that in Romans the 'I' laments, 'It is no longer I doing [evil] but sin dwelling in me.' In Galatians Paul proclaims, 'It is no longer I who live, but Christ who lives in me; and the life I now live in the flesh I live by the faith of the Son of God, who loved me and gave himself for me'. In both cases there is an 'I-yet-notI-but-another' construction of the self. These two contrasting relational identities are thus formally parallel, but they are substantially opposite because the 'other' is radically different. In Galatians 2:20 the relational

${ }^{31}$ Maisel et al., p. 119.

32 Ibid., pp. 80-89.

${ }^{33}$ One may contrast, for example, Simon Baron-Cohen's depiction of evil as the absence of empathy in some human beings. See his Zero Degrees of Empathy: A New Theory of Human Cruelty (London: Allen Lane, 2011). 
partner 'loves me' and 'gave himself for me'. As Paul puts it in Romans $5: 1$, this abundance of divine gift creates an 'arena of grace' in which interpersonal engagement takes place. Similarly, in polar opposition to the 'indwelling sin' that works death, the 'indwelling Spirit of God' will give life to the mortal bodies of Paul's hearers (8:11). Such a relational matrix is indeed second-personal, characterized by a non-competitive, non-transactional account of generous interaction in which divine action promotes the flourishing of human actors. ${ }^{34}$ This is the living relationship, of which the relational system that Paul calls 'sin' is a lifeless copy. It is not life, but sin itself that is 'but a walking shadow. ${ }^{35}$

Are all human interactions one or the other? I do not think so, nor do I think Paul argues for such a radical distinction in human experience in the present time. This is a controversial claim, and it brings me back to the spiral structure of Paul's letter. Why does Paul keep re-telling the story of sin and redemption, moving from a third-person account, to a second-person address, to a first-person performance? I suggest that the repetition serves to name the complexities of human experience caught between the dominion of sin and the reign of grace. Despite Paul's cosmic claims regarding the distinctions between the self-in-relationto-sin and the self-in-relation-to Christ, in felt experience the sequence from the first to the second is not so clear-cut. In Paul's view the cosmic reality is that 'sin' has been dealt a final blow; it has been done away with through the death of Christ (8:3). In fact, after Romans 8:3 sin ceases to play any notable role in the letter. As noted earlier in this essay, Paul employs the third person to narrate this state of affairs. He shifts into second-person plural to encourage his hearers to realize their freedom in union with Christ and shake off the bondage of their subservient relation to sin. But as if recognizing that his listeners' experience may lag far behind this new reality, in Romans 7:7-15 he shifts into first-person singular, employing a method of classical rhetoric known as 'speech in

\footnotetext{
${ }^{34}$ It may seem odd to characterize the Spirit of God as second-personal rather than as an abstract, impersonal entity. Scriptural language about God, however, is intensely personal and affective, and Paul's language in Romans is no exception. The Spirit is the medium of divine love 'poured into our hearts' (5:5); the thoughts and attitudes (phronèma) of the Spirit are life and peace ( 8:6); the Spirit of God 'leads' people (8:14) and 'intercedes' for them $(8: 26)$. Indeed, the Spirit 'bears witness with our spirit that we are children of God' (8:16). The Spirit thus is characterized as a personal agent who operates internally in human lives.
}

35 Shakespeare, Macbeth, Act 5, Scene 5. 
character' or prosopopoeia, which ancient orators used to 'depict and elicit emotion. ${ }^{36}$ And Paul's language is indeed full of pathos. Towards the end of this performance, the speaker cries out, 'Wretched man that I am! Who will deliver me from this body of death?' (7:24).

Here the 'I' describes in profoundly affective language what Paul earlier narrated as the cosmic and corporate reality of human bondage. That is, the speaker assimilates to the emotional experience and attitude of the listener who feels that bondage, thereby inviting her into a responsive identification with the speaker. This is a literary enactment of the 'propensity to identify with the attitudes of others' that Hobson and Hobson name as critical for joint engagement with others. ${ }^{37}$ I suggest that it has the capacity to 'move' the reader motivationally and emotionally as well as cognitively. ${ }^{38}$ The speaker identifies with the reader, the reader identifies with the speaker, and together they hear Paul's words of encouragement: 'There is no condemnation for those who are in Christ Jesus ... the law of the Spirit of life in Christ Jesus has set you free from the law of sin and death.' (8:1-2) This is a movement from joint engagement to joint attention in the context of a gifted relationship.

Finally, this mutual engagement mirrors and enacts God's secondpersonal involvement with humanity. Immediately after announcing liberation from sin, Paul grounds that liberation in God's act of sending 'his own Son in the likeness (en homoiomati) of the flesh of sin and for sin' (8:3). Space precludes a full discussion of this dense and crucial claim for Paul's theology; the point here is that the language of 'likeness' is that of mimetic assimilation to the condition of another, which, in the context of the life of Christ, is also an expression of a desire for the good of the other and for union with the other. ${ }^{39}$ God in Christ moves into the human condition, assimilates to it, is attuned to it. The logic of Paul's second-personal appeal to the Romans proceeds from this embodied

\footnotetext{
${ }^{36}$ Stanley K. Stowers, A Rereading of Romans: Justice, Jews, and Gentiles (New Haven: Yale University Press, 1994), p. 20.

37 'Joint Attention or Joint Engagement?', pp. 117, 130.

38 Ibid.

${ }^{39}$ For exegetical and critical support of this claim, see my 'Philippians 2:6-11: Incarnation as Mimetic Participation', Journal for the Study of Paul and his Letters, 1.1 (Fall 2010), 1-22. A finely-tuned definition of the twofold desires of loving union with another is offered by Silverman as follows: 'a disposition towards relationally appropriate acts of the will consisting of disinterested desires for the good of the beloved and unity with the beloved held as final ends.' See Eric J. Silverman, The Prudence of Love: How Possessing the Virtue of Love Benefits the Lover (Lexington Books, 2010), p. 59.
} 
divine participation in the human condition, which in turn invites and instigates a responsive second-personal engagement with God in Christ.

\section{CONCLUSION}

Paul would find himself at home in second-person accounts of the development of personhood through participation in primary relationships that irreducibly shape us. For Paul, human agents never act alone; they always are constituted in interpersonal matrices that also are internalized. Human agents always are selves-in-relation-to-another, and hence also breathtakingly vulnerable to malign relational networks that appropriate aspects of what would today be called second-person relatedness but lead to destructive ends. It is impossible to opt out of this condition of relatedness, which is necessary for human flourishing and yet renders a person vulnerable in the absence of a more potent relationship of love. Indeed, for Paul, as also for contemporary accounts of the constitution of personhood in terms of second-person relatedness, there are no freestanding individuals, but only selves constituted through participation in intersubjective engagements characterized either by sin or by the grace of God in Christ. The first kind of engagement is transactional, competitive, unidirectional, and domineering, operating implicitly within an economy of lack or emptiness. Within this deficient interpersonal environment the actions of the human agent become dissociated from her wants or, more precisely, there is no longer a wholly coherent meaning to what 'she' wants because she is internally divided. This is a picture of pseudo second-personal relatedness; a sort of pseudo engagement that appropriates aspects of the form but lacks the bond of love that underwrites genuine joint attention and interaction. In contrast, Paul's account in Romans of the divine action that moves persons into a new identity of self-in-relationship demonstrates genuinely secondpersonal qualities: it is loving, non-transactional, non-competitive, mutually responsive, and constitutive of human agents who may thereby 'reign in life through the one man, Jesus Christ' (5:17). 


\section{BIBLIOGRAPHY}

Barclay, John M. G., 'Under Grace: The Christ-Gift and the Construction of a Christian Habitus', in Beverly R. Gaventa, ed., Apocalyptic Paul: Cosmos and Anthropos in Romans 5-8 (Waco: Baylor University Press, 2013), pp. 59-76

Baron-Cohen, Simon, Zero Degrees of Empathy: A New Theory of Human Cruelty (London: Allen Lane, 2011)

Delbanco, Andrew, The Death of Satan: How Americans Have Lost the Sense of Evil (New York: Farrar, Straus \& Giroux, 1995)

Eastman, Susan, 'Double Participation and the Responsible Self in Romans 5-8', in Beverly R. Gaventa, ed., Apocalyptic Paul: Cosmos and Anthropos in Romans 5-8 (Waco: Baylor University Press, 2013), pp. 93-110

Eastman, Susan, 'Philippians 2:6-11: Incarnation as Mimetic Participation', Journal for the Study of Paul and his Letters, 1.1 (Fall 2010), pp. 1-22

Garrels, Scott, 'Imitation, Mirror Neurons, and Mimetic Desire: Convergence Between the Mimetic Theory of René Girard and Empirical Research on Imitation, in Contagion: Journal of Violence, Mimesis, and Culture, Issue 1213 (2005-2006), 47-86

Hobson, Peter, The Cradle of Thought (London: MacMillan, 2002)

Hobson, Peter, and Jessica Hobson, 'Joint Attention or Joint Engagement? Insights from Autism, in Axel Seemann, ed., Joint Attention: New Developments in Psychology, Philosophy of Mind, and Social Neuroscience (Cambridge, MA: MIT Press, 2011), pp. 115-136

Hobson, Peter, 'What Puts Jointness into Joint Attention?', in Naomi Eilan et.al., eds., Joint Attention: Communication and Other Minds: Issues in Philosophy and Psychology (Oxford: Clarendon Press, 2005), pp. 185-204

Hofius, Otfried, 'Der Mensch im Schatten Adams', in Paulusstudien II (WUNT 143; Tübingen: Mohr Siebeck, 2002), pp. 104-154

Jewett, Robert, Romans: A Commentary (Hermeneia; Minneapolis: Fortress, 2007)

Keck, Leander, Romans (Abingdon New Testament Commentaries: Nashville: Abingdon, 2005)

Keck, Leander, 'What Makes Romans Tick?', in David M. Hay and E. E. Johnson, eds., Pauline Theology: Volume III: Romans (Minneapolis: Fortress, 1995), pp. 3-29

Maisel, Richard, David Epston, and Ali Borden, Biting the Hand that Starves You: Inspiring Resistance to Anorexia/Bulimia (New York: W. W. Norton \& Company, 2004)

Meltzoff, Andrew and M.K. Moore, 'Imitation of Facial and Manual Gestures by Human Neonates', Science, 198 (1977), 75-78

Meyer, Paul W., 'Romans: A Commentary', in The Word in This World: Essays in New Testament Exegesis and Theology (NTL; Louisville: Westminster John Knox, 2004) 
Meyer, Paul W., 'The Worm at the Core of the Apple: Exegetical Reflections on Romans 7, in The Word in This World: Essays in New Testament Exegesis and Theology (NTL; Louisville: Westminster John Knox, 2004), pp. 57-77

Pacherie, Elisabeth, 'The Phenomenology of Joint Action: Self-Agency versus Joint Agency', in Axel Seemann, ed., Joint Attention: New Developments in Psychology, Philosophy of Mind, and Social Neuroscience (Cambridge, MA: MIT Press, 2011), pp. 343-390

Pinsent, Andrew, The Second-Person Perspective in Aquinas's Ethics: Virtues and Gifts (New York; London: Routledge, 2012)

Reddy, Vasudevi, 'A Gaze at Grips with Me', in Axel Seemann, ed., Joint Attention: New Developments in Psychology, Philosophy of Mind, and Social Neuroscience (Cambridge, MA: MIT Press, 2011), pp. 137-157

Reddy, Vasudevi, 'Before the "Third Element": Understanding Attention to Self', in Naomi Eilan et.al., eds., Joint Attention: Communication and Other Minds: Issues in Philosophy and Psychology (Oxford: Clarendon Press, 2005), pp. 85-109

Reddy, Vasudevi, How Infants Know Minds (Cambridge, MA: Harvard University Press, 2008)

Roessler, Johannes, 'Joint Attention and the Problem of Other Minds', in Naomi Eilan et al., eds., Joint Attention: Communication and Other Minds: Issues in Philosophy and Psychology (Oxford: Clarendon Press, 2005), pp. 230- 233

Silverman, Eric J., The Prudence of Love: How Possessing the Virtue of Love Benefits the Lover (Lexington Books, 2010)

Stowers, Stanley K., A Rereading of Romans: Justice, Jews, and Gentiles (New Haven: Yale University Press, 1994)

Stump, Eleanore, Wandering in Darkness: Narrative and the Problem of Suffering (Oxford: Oxford University Press, 2010)

Williams, Rowan, Lost Icons: Reflections on Cultural Bereavement (London; New York: Continuum, 2003) 